Chapter 22

\title{
Chemical and Hydraulic Behavior of a Tropical Soil Compacted Submitted to the Flow of Gasoline Hydrocarbons
}

\author{
Wisley Moreira Farias, Geraldo Resende Boaventura, \\ Éder de Souza Martins, \\ Fabrício Bueno da Fonseca Cardoso, \\ José Camapum de Carvalho and \\ Edi Mendes Guimarães
}

Additional information is available at the end of the chapter

http://dx.doi.org/10.5772/57234

\section{Introduction}

Gasoline is a fuel comprised basically of hydrocarbons such as aromatic, olefinic and saturated compounds of a carbon chain comprised of 4 to 12 atoms. The aromatic compounds such as benzene, toluene, ethylbenzene, $o-, m-, p$-xylene (BTEX) are harmful to human health (Cairney et. al., 2002). As these compounds are harmful to health, the legislation becomes restrictive. The U.S. Environmental Protection Agency for drinking water (US EPA) establishes the maximum concentration of benzene in $5 \mu \mathrm{g} . \mathrm{L}^{-1}$. In Brazil the Ordinance of the Ministry of health number 2,914 in 12th December 2011, stipulates that the maximum allowable concentration of benzene is $5 \mu \mathrm{g} . \mathrm{L}^{-1}$ regulation of drinking water contaminant. Soil in contaminated residential areas, Brazil has been adopting as intervention guide value, the concentration of benzene 0.08 mg.kg ${ }^{-1}$ set by the State of São Paulo in 2001. This value indicates the intervention limit of contamination where there is potential risk to human health.

Brazil produces type- $C$ gasoline which is different than other types due to its anhydrous alcohol content (ethanol), in the proportion of 25\% (Farias, 2003). The alcohols are soluble in water, and have a significant mobility potential to percolate through the soil until reaching underground water (Ulrich, 1999; Corseuil and Fernandes, 1999). The alcohol in gasoline in an 
aqueous medium promotes co-solvency which is the increase in the solubility of the hydrocarbons in the gasoline in an aqueous solution (Banerjee and Yalkowsky, 1988; Cline et al., 1991).

Solubility is generally controlled by the polarity effect, which decreases in size for molecules with the same organic function. Non-polar or weakly polar substances dissolve in similar solvents. Thus, highly polar compounds dissolve in polar solvents such as water. The polarity or dipolar moment is proportional to the dielectric constant, and therefore high dielectric constant compounds (values of 80 for water and 34 for methanol) dissolve ions through hydration of the disassociated types (Fernandez and Quigley, 1985).

On the surface of clay-minerals, the absorbed water forms a double layer, which reduces the strength of interaction between the negatively charged clay particles and the cations in the colloidal solution. The hydrophobic hydrocarbons in the gasoline have low dielectric constant values, thus provoking the collapse of the double layer. This collapse is due to the contraction of the double layer through the attraction of the contra-ions which are closer to the superficial charge of the clay-minerals, favoring flocculation, and consequently the increase in permeability due to the increase in pore space (Mesri and Olson, 1971; Fernandez and Quigley, 1985 and 1988).

The co-solvêncy is responsible for the partition of BTXs to the aqueous phase, promoting the reduction of density of colloidal solution of soil, providing increased viscosity and a reduction of the surface tension (Mcdowell and Powers, 2003). This reduction in surface tension and generated by the collapse of the electrical double layer that there was between the soil and water (Farias, 2003).

\subsection{Aspects of the transport of pollutants in soils}

The transport of pollutants in the soil can occur through the porous medium and saturated or unsaturated fractured media. This transportation occurs through physical or chemical processes, or through both processes. The chemical process becomes evident when the velocity of the fluid is not sufficiently high (i.e., less than $10^{-6} \mathrm{~cm} / \mathrm{s}$ ), generating a gradient due to the flow of the solute (contaminating agent) from the more concentrated medium to the less concentrated one. This process is called molecular diffusion (Rowe, 1988; Pastore and Mioto, 2000). This type of flow has been widely studied with metals and organic compounds in solid waste landfill leachate contaminants, for application in compacted soil layer, also called liners (Shackelford and Daniel, 1991; Rowe, 1988; Barone et al., 1988).

Fernandez and Quigley (1985) developed an experimental research program to evaluate the hydraulic behavior of clayey-like soil (Sarnia, Ontario), permeated with liquid substances such as benzene, xylene, cyclohexane, aniline, propanol, acetone, alcohol and water. The results have shown that Hydraulic conductivity increased from $5 \times 10^{-9}$ to $1 \times 10^{-4} \mathrm{~cm} \cdot \mathrm{s}^{-1}$ along with a decrease in the dielectric constant from 80 (water) to 2 (benzene).

When there is a hydraulic gradient, the velocity of the solvent is relatively high and the transportation of the solute is practically managed by the velocity of the solvent, a mechanism 
which is known as an advection process. In this process, the velocity of the fluid is governed by Darcy's Law, which considers not only the characteristics of the soil, but also those of the fluid (Fernandez and Quigley, 1988).

In order to have good performance, the compacted clay liners must have a hydraulic conductivity less than $10^{-8} \mathrm{~cm} / \mathrm{s}$. However Daniel and Koerner (1995) defined that the hydraulic conductivity of clay liners must be less than or equal to $10^{-7} \mathrm{~cm} / \mathrm{s}$. This low flow is normally associated with the presence of clay-minerals, and at least 15 to $20 \%$ of particles with sizes under $2 \mathrm{~mm}$, as well as a minimum plasticity greater than $7 \%$, activity greater than 0.3 , and cation exchange capacity (CEC) greater than $100 \mathrm{mmol}_{\mathrm{c}} / \mathrm{dm}^{3}$ of soil (Rowe et al.,1995).

The natural organic material of the soils have proven to be efficient in the retarding process through the sorption of hydrophobic hydrocarbons, which are also found in gasoline (Chiou et al., 1983; Karickhoff et al., 1979; Schwarzenbach et al., 1993).

\subsection{Importance of research}

The aim of this study is to evaluate the behavior of a tropical soil, and their performance as liner against the flow of hydrocarbons from gasoline, by interpreting transportation according to physical and chemical parameters, as well as micromorphological aspects. For this characterized the mineralogy of the soil and the influence of his organic matter (OM), considering the adsorption processes of hydrocarbons from gasoline and hydraulic behavior in the laboratory by variation of the hydraulic gradient in front of the gasoline flow through compacted soil. This study also aims to contribute to the understanding of the dynamics of the flow through the soil of specific groups of compounds: aromatic, olephine, saturated hydrocarbons and the ethanol found in Brazilian type-C gasoline (a complex mixture of organic compounds).

\section{Location and Soil classification}

The soil sample was collected indisturbed block in depth of $4 \mathrm{~m}$ in the experimental field of foundations and test field of the Civil Engineering Department of the University of Brasília, located on the University campus in the city of Brasília, Brazil with coordinates $15^{\circ} 56^{\prime} 45$ "S, $47^{\circ} 52$ ' 20" W (Fig. 1).

The sample of lateritic soil typical of the Brazilian cerrado region was studied. According to the Brazilian Soil Classification System (Embrapa, 1999), the soil was classified as Red Latossoil, considered as Ustic Rhodic Oxisol according to the U.S. Soil Taxonomy and Geric Ferralsol Ferric (FAO, IUSS Working Group WRB, 2007). It possesses a silt-clay-like texture, a large quantity of granular aggregates, and small pores. Visually, it is homogeneous and isotropic, without the presence of discontinuities. 


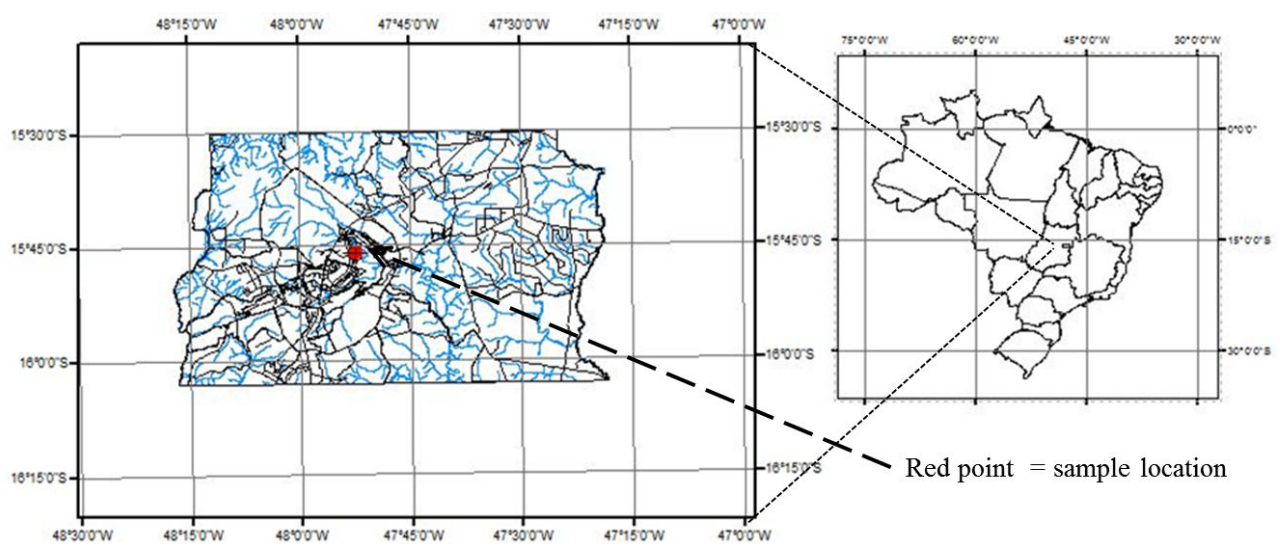

Figure 1. Map of location of the soil collection.

\section{Methodology}

The characterization of the soil involved the use of physical, chemical and mineralogical analysis.

\subsection{Physical tests}

Geotechnical tests of physical properties of soils were performed following the Brazilian Association of Technical Standards (ABNT) procedures: test of limits of consistency called Atterberg limits following the ABNT NBR 7180/84 plastic limit; 6459/84 liquid limit following the Casagrande method. Before the grain-size determination, the real density was determined according the ABNT NBR 6508/84 method. The grain-size distribution curve was determined using a grain-size digital meter Malvern Mastersizer with lens de 300Rf for grain size range of $0.05 \mu \mathrm{m}$ to $900 \mu \mathrm{m}$ at $25^{\circ} \mathrm{C}$. For this analysis, the sample was previously passed through a No. 40 sieve. The analyses of the samples were done either with or without ultrasound dispersion. Ultrasonic condition was 5 minutes of dispersion in distilled water with ultrasonic level set at 5. The grain size fractions were classified following the Brazilian standard NBR 6502/93.

The degree of flocculation and dispersion of soil particles was determined comparing the results of grain size determinations before and after ultrasonic dispersion.

\subsubsection{Hydraulic conductivity}

The test of hydraulic conductivity in compacted soil in standard Proctor energy were performed in a conventional manner with water using the variable charge and special form for gasoline (Fig. 2 and Fig. 3). 


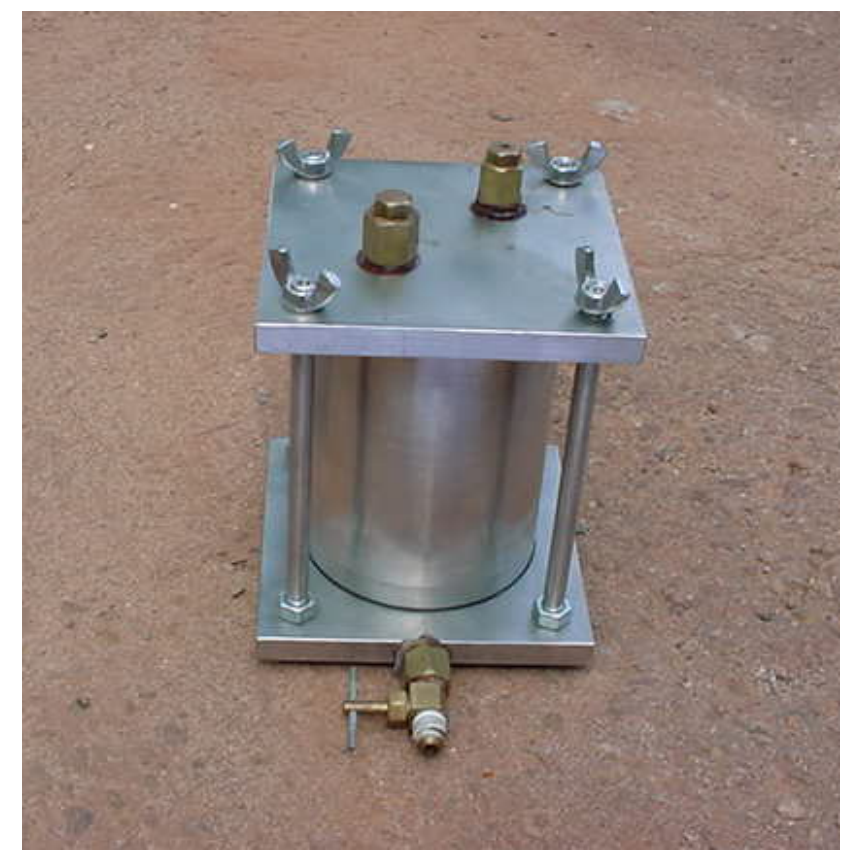

Figure 2. Hydraulic Conductivity cell.

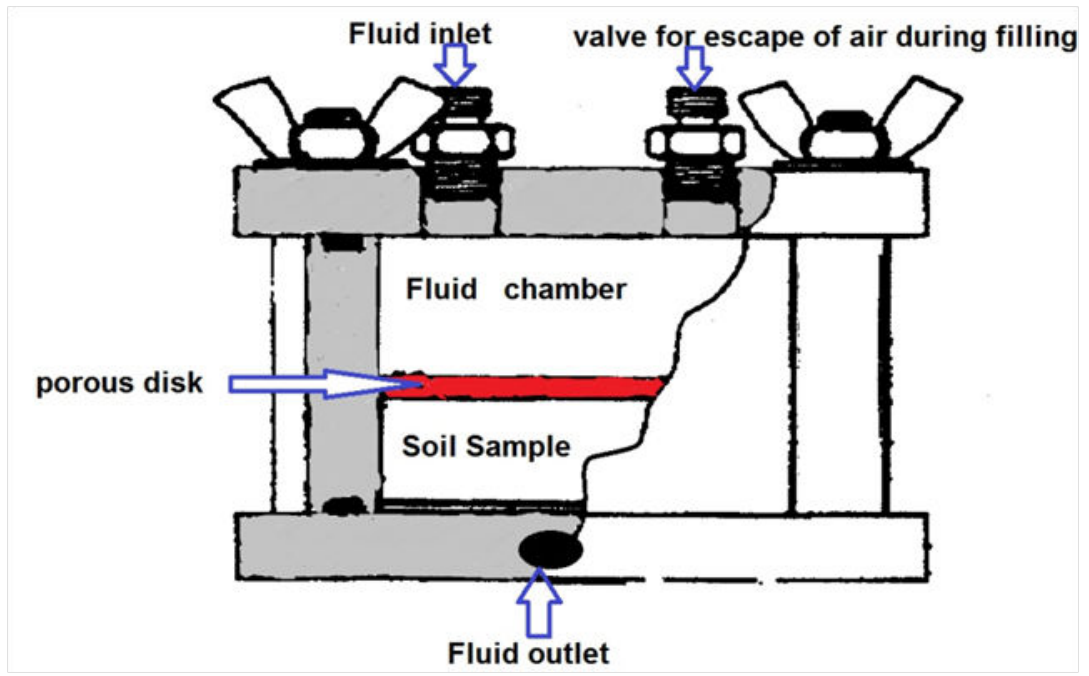

Figure 3. Schematic of permeameter Cell. 
The gasoline hydrocarbons, for possessing volatile and low-density compounds require a special sealed cell to avoid losses due to evaporation and leakage and to support the applied tensions. The material selected for the construction of the special cells was stainless steel, to avoid reaction and adsorption problems in the walls, which is the case of plastics and acrylics (Doanhue et al., 1999).

The system used to perform the gasoline's hydraulic conductivity was similar to that applied by Fernandes (1989). The special cell may be disassembled, and is made up of three parts. The first part is a cylinder, where the test material and reservoir are found. This part is $5 \mathrm{~mm}$ thick, $110 \mathrm{~mm}$ long and has an internal diameter of $77.2 \mathrm{~mm}$. The other two parts are the upper and lower lids. Both have cavities filled with rubber rings which are able to prevent the reaction of the hydrocarbons in the gasoline and act as a seal when the cylinder is assembled. The upper lid has two openings, one for the entry of fluid and the other for the application of vertical tension with compressed air. The lower lid is made up of an outgoing flow register which is connected to a collecting container. The two lids are $120 \times 120 \mathrm{~mm}^{2}$ square, $10 \mathrm{~mm}$ thick. The connections were made out of aluminum, due to its low cost and flexibility; the connecting joints were sealed with $3 \mathrm{M}$ automotive glue and winding sealing thread, in order to prevent leaks and to make the system more secure.

The conductivity test was performed with test material $5 \mathrm{~cm}$ long, compacted at normal Proctor energy at optimal water content condition, in the cylinder of the hydraulic conductivity cell. Then, a thin disk of porous ceramic was placed top of the sample. The small space between the disk and the cylinder wall was filled with $3 \mathrm{M}$ glue to prevent preferential flows along the wall, and to ensure that the gasoline only passed through the porous ceramic disk. The cell was then assembled, and the upper and lower lids were connected to the cylinder. The cylinder is $11 \mathrm{~cm}$ high, of which the remaining $6 \mathrm{~cm}$ were filled with type $C$ gasoline. After the cell was totally sealed and connected to the compressed air system, with pressure controlled by a manometer, it was connected with plastic tubes able to support high pressure. The conductivity tests were performed for various applied vertical pressures. For each pressure applied, the hydraulic conductivity was measured. The pressures were varied to see how the soil sample behaved with an increase in hydraulic gradient upon the flow of gasoline. The hydraulic conductivity was measured in the laboratory at static tensions $\sigma_{v}$ of 50, 100, 150, 200, and $300 \mathrm{kPa}$, with respective hydraulic gradients of 75, 150, 225, 300, and 450.

The residual water of the soil pores mixed with gasoline collected in the test was previously run through a separating funnel to remove the aqueous phase to later take a reading of hydrocarbons of the gasoline through infrared technique.

The test material of the lateritic soil sample, before and after the hydraulic conductivity test conducted with water, and the other with the flow of gasoline, were dried at room temperature. Micromorphological analyses were performed on Thin Lamina (TL) in vertical sections, prepared by impregnating the sample with plastic resin (Cardoso, 1995; Martins, 2002). The instrumental technique used for the microscopic views of the TL was Optical Microscopy. 


\subsection{Mineralogical characterization}

The identification and quantification of minerals in the sample were carried out by the method developed by Martins (2000). This method involves the use of X-ray diffraction (XRD) technique for identifying the minerals, chemical analysis for the determination of major elements (Al, Fe, Si, Ca, Mg and Ti), thermogravimetric analysis (TGA), and the use of Munsell color code (Munsell color company Inc., 1975). The determination of major chemical elements was performed by ICP-AES after the fusion of samples with alkaline $\mathrm{NaOH}$ as fondant at a temperature of $450^{\circ} \mathrm{C}$ for 40 minutes using the nickel crucible. Determinations of elements by ICP / AES (atomic emission spectrometry of Plasma Induced Coupling) were performed with Thermo Jarrell ASH equipment, model Iris / AP.

The thermogravimetric analysis were applied to quantify the kaolinite and gibbsite. For this used the TGA Shimadzu equipment with temperature ramp of $20^{\circ} \mathrm{C}$ to $1500{ }^{\circ} \mathrm{C}$, with speeds ranging from 0.2 to $60^{\circ} \mathrm{C} / \mathrm{min}$, using the software TAS60WS for the treatment of data. The Munsell code was used for determining the ratio of hematite and goethite in the soil samples. The CEC of soil was determined using the principle of the simple as the sum total of the exchangeable cations that a soil can adsorb. The determination of the organic matter content was done prior to extraction using wet oxidation method with potassium dichromate in sulfuric medium. The excess of dichromate after oxidation was titrated with standard solution of ferrous ammonium sulfate (Mohr salt).

\subsection{Chemical characterization}

The $\mathrm{pH}$ was measured in the soils samples in distilled water medium using a combined glass electrode $\mathrm{Ag} / \mathrm{AgCl}$ (potentiometric method).

In order to study the influence of OM and mineralogy in the gasoline sorption process, an experiment was performed with samples treated with $\mathrm{H}_{2} \mathrm{O}_{2}$ and another without treatment.

The extraction of the OM used $15 \mathrm{~g}$ of soil in a porcelain capsule, with $10 \mathrm{~mL}$ of $\mathrm{H}_{2} \mathrm{O}_{2}$ volume $30 \%$ and with agitation in a $50 \mathrm{~mL}$ Becker cup. After agitation, there was an effervescent reaction, when the capsule was covered with clock glass for one night. The process was repeated until the complete disappearance of the reaction. It was then washed 3 to 5 times in distilled water, using a Büchner funnel with filtering under reduced pressure. Then, for the gasoline sorption test, the sample was allowed to dry at room temperature.

The sorption test procedure used $2 \mathrm{~g}$ of soil with $25 \mathrm{~mL}$ of gasoline placed in an amber glass jar under agitation for 24 hours at a temperature of $22^{\circ} \mathrm{C}$. After this, the samples were centrifuged as in the processes described above, with the removal of a $15 \mathrm{~mL}$ portion for analysis.

The hydrocarbons content of the gasoline samples was determined at the National Petroleum Agency (ANP) laboratory, in Brasilia, with a (FTIR = Fourier Transform Infrared), manufactured by Grabner Instruments, model IROX 2000. This instrument qualified and quantified the compounds, generating the mass and volume percentages of the ethanol, aromatic, olephine and saturated compounds. 


\section{Results}

Tab. 1 and 2 present data of the physical, chemical and mineralogical Brazilian soil and constituents of the gasoline type $\mathrm{C}$ studied.

\begin{tabular}{|c|c|}
\hline Test & Lateritic \\
\hline \multicolumn{2}{|l|}{ Atterberg Limits } \\
\hline Liquid limit-W $\mathrm{W}_{\mathrm{L}}(\%)$ & 41 \\
\hline Plastic limit-W $W_{p}(\%)$ & 29 \\
\hline Plastic Index-I $(\%)$ & 12 \\
\hline Activity & 0,18 \\
\hline \multicolumn{2}{|l|}{ Grain size distribution* } \\
\hline Clay (\%) & 65 \\
\hline Silt (\%) & 34 \\
\hline Sand(\%) & 1 \\
\hline Degree of flocculation (\%) & 92 \\
\hline Degree of dispersion (\%) & 8 \\
\hline \multicolumn{2}{|l|}{ Chemical Parameters } \\
\hline $\mathrm{pH}$ & 5,70 \\
\hline Organic Matter content (\%) & 0,41 \\
\hline $\mathrm{CEC}\left(\mathrm{mmol}_{\mathrm{c}} / \mathrm{dm}^{3}\right)$ & 6,4 \\
\hline \multicolumn{2}{|l|}{ Mineralogy } \\
\hline Quartz (\%) & 30,2 \\
\hline Anatase (\%) & 1,57 \\
\hline Kaolinite(\%) & 24,6 \\
\hline Gibbsite (\%) & 25,5 \\
\hline Goethite (\%) & 4,6 \\
\hline Hematite (\%) & 7,5 \\
\hline Illite (\%) & 2,2 \\
\hline Vermiculite (\%) & 3,7 \\
\hline Hydraulic Conductivity in water (cm/s) & 3,7.E-07 \\
\hline
\end{tabular}

*Grain size data obtained by ultra-sound waves using a laser beam grain size analyser.

Table 1. Characteristics of the soil (Farias, 2003).

Tab. 2 presents the composition of the Brazilian type-C gasoline, according to Farias (2003). 


\begin{tabular}{cc}
\hline Compounds & Mass (\%) \\
\hline Aromatics & 20,8 \\
\hline Olefins & 22,4 \\
\hline Saturated & 31,4 \\
\hline Ethanol & 25,4 \\
\hline
\end{tabular}

Table 2. Brazilian Type C gasoline data.

Fig. 4 presents the increase in hydraulic conductivity with an increase in the hydraulic gradient. At a gradient of approximately 210, conductivity becomes practically constant. Fig. 5 presents the intrinsic permeability, which considers the characteristics of the soil, but does not consider the chemical and physical properties of the fluid. Intrinsic permeability reaches values close to $10^{-13} \mathrm{~m}^{2}$. However, as the hydraulic gradient increases, stability reaches approximately $10^{-11} \mathrm{~m}^{2}$.

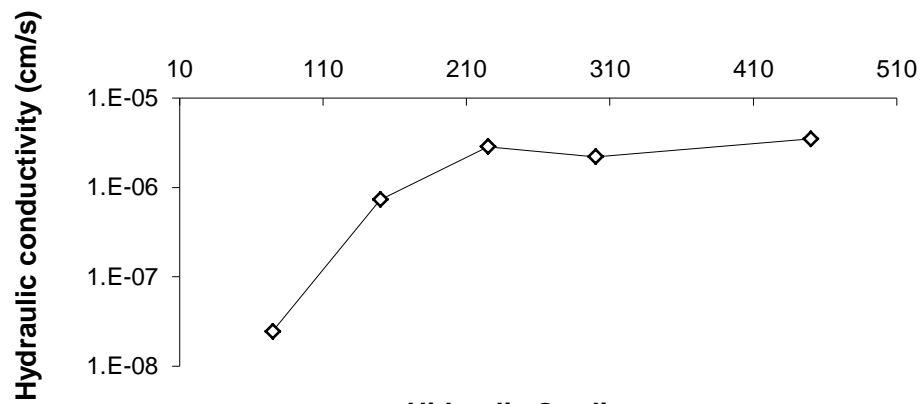

Hidraulic Gradient

Figure 4. Behavior of hydraulic conductivity and hydraulic gradient of laterite soil on the gasoline flow.

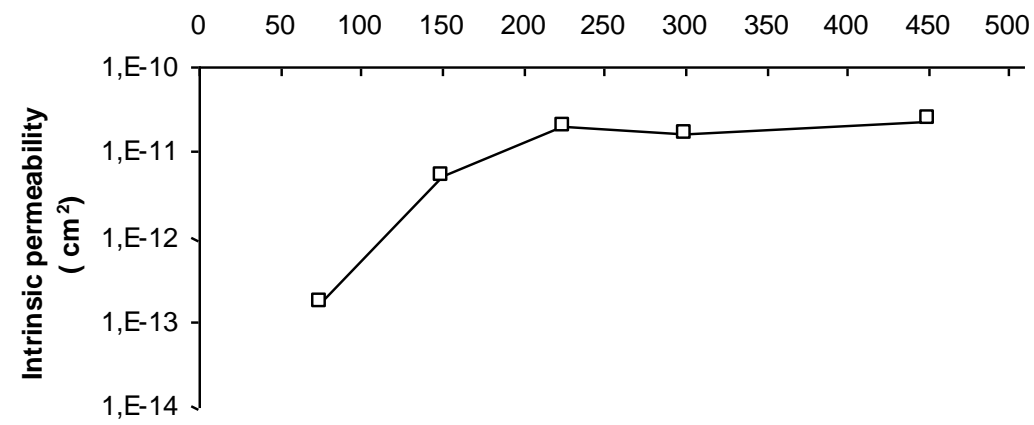

Hydraulic Gradient

Figure 5. Behavior of the intrinsic permeability and hydraulic gradient of laterite soil on the gasoline flow. 
Fig. 6 depicts the behavior of the hydraulic conductivity relative to the volume of pores while undergoing saturation in the test material with gasoline at a tension of $\sigma_{v}$ of $50 \mathrm{kPa}$. The saturation process takes place with the expulsion of the interstitial water accumulated in the pores due to optimal compacting moisture content $\left(\mathrm{w}_{\mathrm{opt}}=26 \%\right)$ is the test material at normal Proctor energy. It may be observed that as the volume of pores in the gasoline flow increases, conductivity decreases from 4 to $2 \times 10^{-8} \mathrm{~cm} \cdot \mathrm{s}^{-1}$. This suggests that the behavior of the reduction may be represented by a second-order equation.

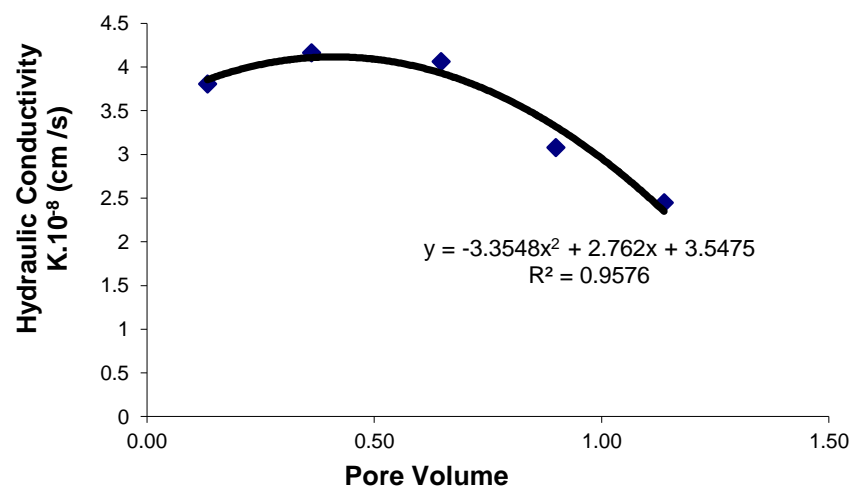

Figure 6. Behavior of the lateritic soil saturated with gasoline at $50 \mathrm{kPa}$.

Fig. 7 presents the saturation process at a $\sigma_{v}$ tension of $50 \mathrm{kPa}$, based on the ratio between the concentration $(\mathrm{C})$ of the gasoline hydrocarbons passing through the soil sample, and the initial concentration $\left(\mathbf{C}_{\mathrm{o}}\right)$ added to the reservoir, in relative to the volume of pores. The hydrocarbons concentration data are from the Light Non-aqueous Liquid Phase (LNALP), after the flow through the soil sample in the hydraulic conductivity test.

\begin{tabular}{|c|c|c|c|c|c|c|c|c|}
\hline Sample & $\begin{array}{l}w \\
(\%)\end{array}$ & $\begin{array}{c}Y \\
\left(k N \cdot m^{-3}\right)\end{array}$ & $\begin{array}{c}\mathbf{V}_{\mathrm{dmax}} \\
\left(\mathbf{k N} \cdot \mathrm{m}^{-3}\right)\end{array}$ & $\begin{array}{c}V_{\mathrm{s}} \\
\left(\mathrm{kN} \cdot \mathrm{m}^{-3}\right)\end{array}$ & e & $\mathbf{n}$ & $\begin{array}{l}\text { S r } \\
(\%)\end{array}$ & $\begin{array}{l}\mathrm{Vv} \\
\mathrm{cm}^{3}\end{array}$ \\
\hline lateritic* & 1,7 & 17,7 & 17,4 & 27,5 & 0,58 & 0,4 & 8,1 & 134,3 \\
\hline lateritic** & 1,7 & 15,8 & 15,6 & 27,5 & 0,77 & 0,4 & 6,2 & 178,5 \\
\hline lateritic*** & 1,8 & 14,7 & 14,5 & 27,5 & 0,90 & 0,5 & 5,3 & 210,0 \\
\hline
\end{tabular}

*Dry soil sample before the hydraulic conductivity test

${ }^{* *}$ Dry soil sample after the hydraulic conductivity test with the water flow

*** Dry Soil sample after the hydraulic conductivity test with the gasoline flow

Table 3. Result of the physical parameters of the test material. 
The results in Tab. 3 present the physical parameters of the compacted test materials dried at room temperature before and after the hydraulic conductivity test. Highlights the volume of voids (Vv), which changes substantially when there is a flow of gasoline. The degree of saturation also decreases after the flow of gasoline.

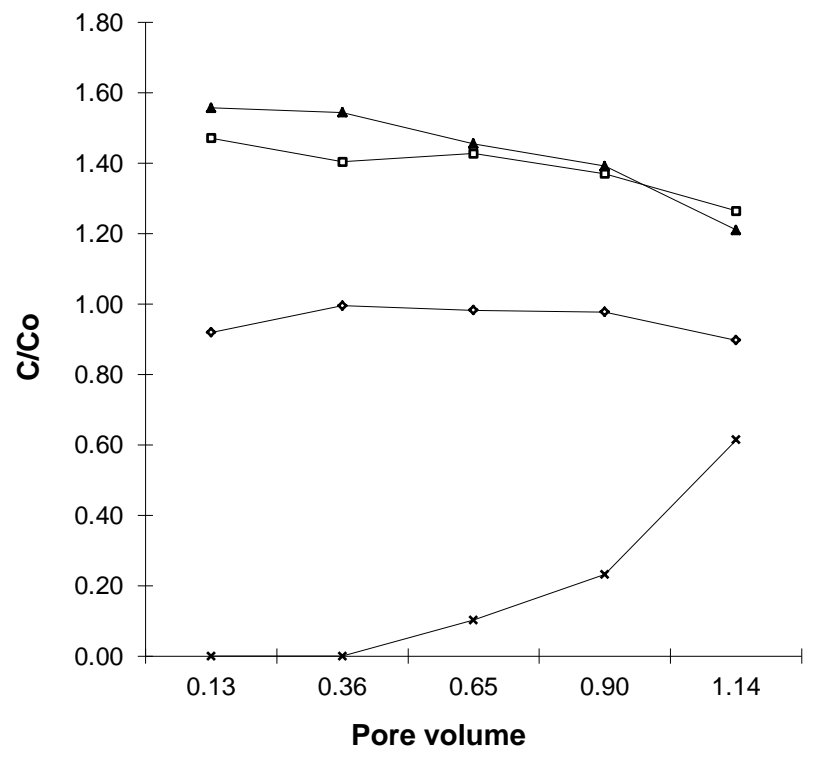

Figure 7. Light non-aqueous liquid phase ratio of the gasoline relative to the volume of pores of the lateritic soil in a saturation process at $50 \mathrm{kPa}$.

The micromorphology of the three compacted soil samples was important in order to visualize the behavior of the test material before the hydraulic flow (Fig. 8), after the hydraulic flow with water, and after the flow with gasoline. It must be noted that the grains of quartz make up approximately $40 \%$ of the total solid material; variable in size, $0.12 \mathrm{~mm}$ on average; and overall, are sub-rounded to angular. They are highly fractured, without orientation and their contours present corrosion. In spite of the compacting, the structure of this soil is not totally dispersed, for microaggregations of oxyhydroxides of $\mathrm{Fe}$ and $\mathrm{Al}$ remain, forming micropores. The compacted soil sample submitted to percolation in water showed a single micro-structural difference relative to the one performed on the LT of the compacted soil sample. Actually, there was an increase in small canal-type voids, generated by the flow of water (Fig. 9). The micromorphology regarding the LT of the compacted soil submitted to the flow of gasoline also showed only a quantitative increase in canal-type voids (Fig. 10). However, this variation was greater than that registered in the previous sample with the water flow. 


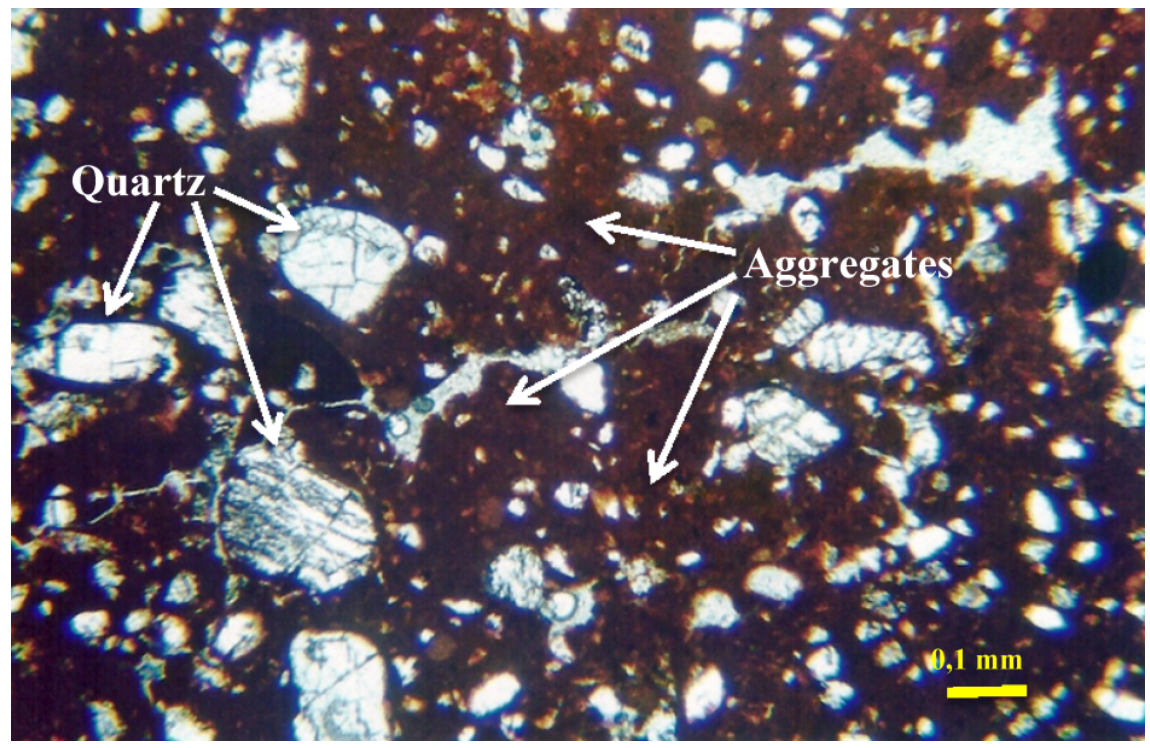

Figure 8. Photomicrography of the porfirosquelic APE, aggregates, and quartz grains of the compacted lateritic soil. Parallel nichols (N//).

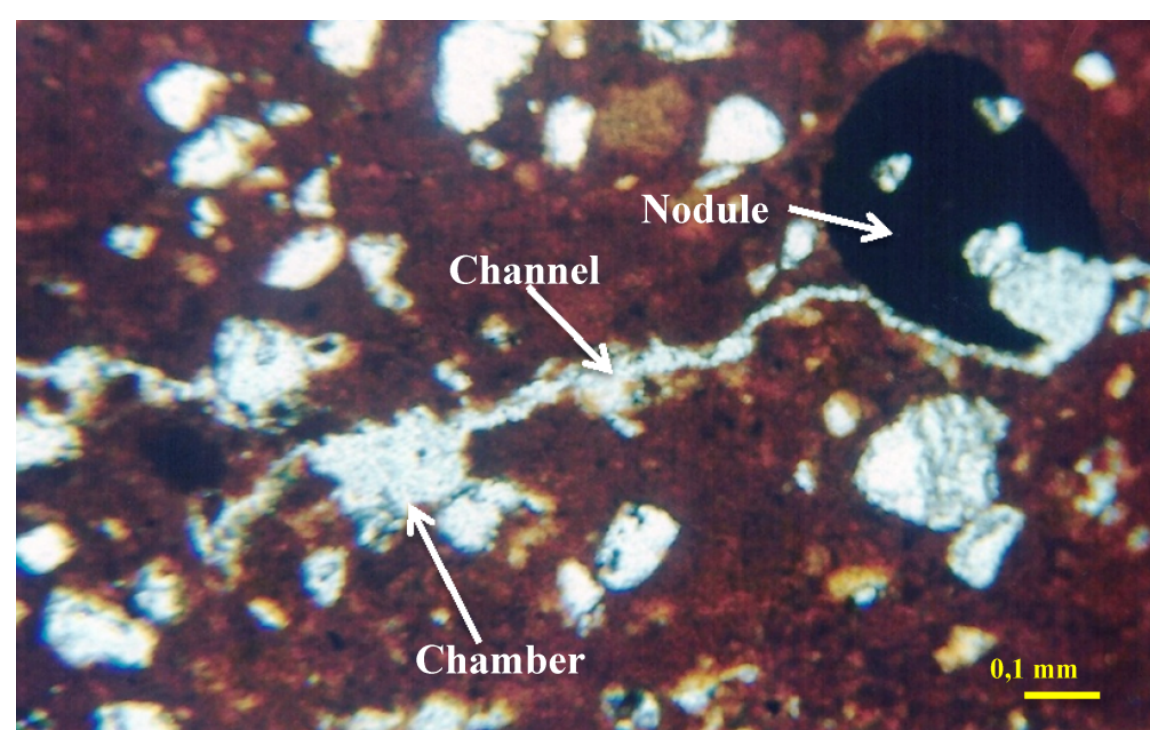

Figure 9. Photomicrography showing the nodules and canal- and chamber-type voids of the compacted lateritic soil submitted to percolation with water. Parallel nichols (N//). 


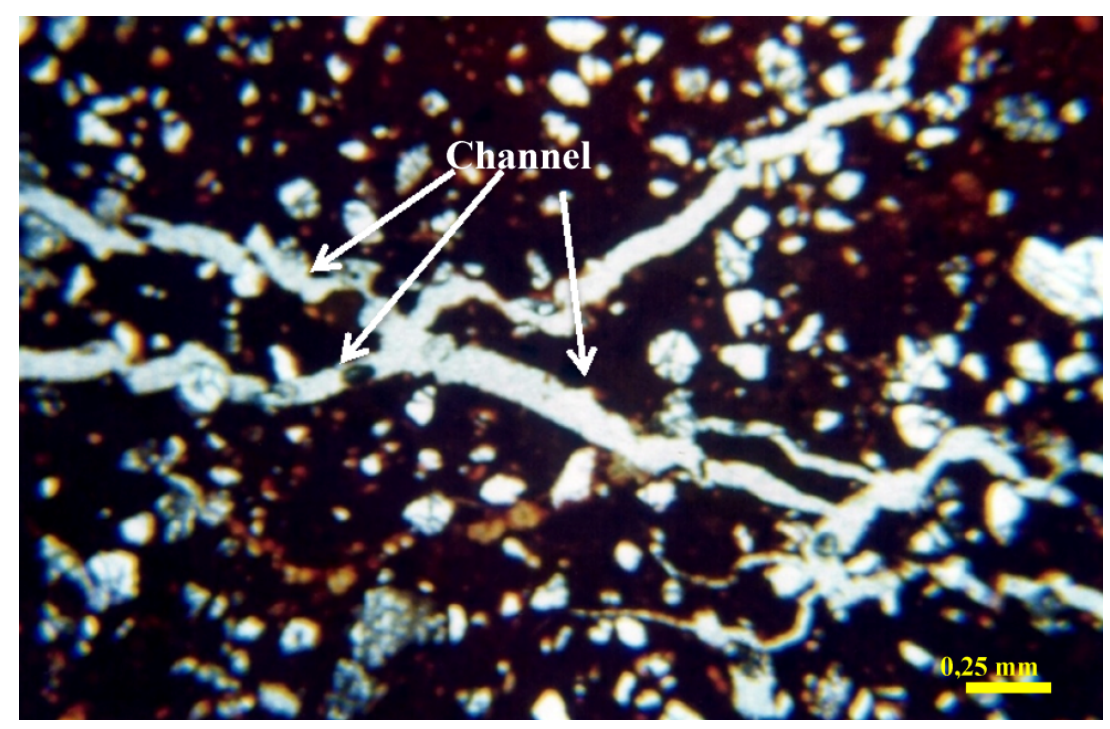

Figure 10. Photomicrography showing the canal-type voids of the compacted lateritic soil submitted to percolation with gasoline. Parallel nichols (N//).

Fig. 11 presents the results of the adsorption of the ethanol and aromatic substances in the samples with and without the extraction of organic matter with the use of hydrogen peroxide. Note that the samples treated with extractor presented low adsorption. Aromatic compounds showed no adsorption after extraction of organic matter contained in the soil.

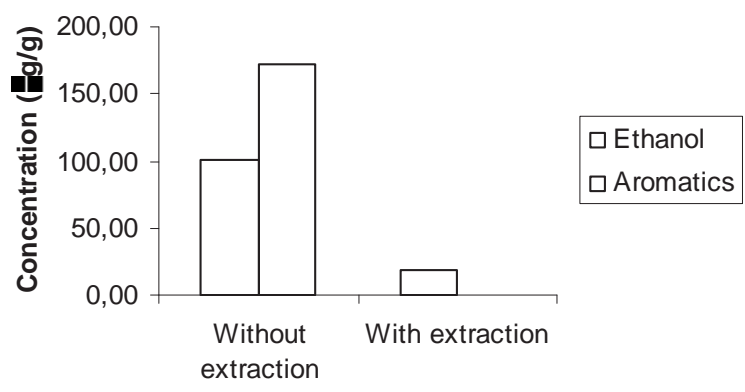

Figure 11. Results of the adsorption of the gasoline hydrocarbons in the soils with and without the extraction of the soil organic matter.

Gasoline ethanol can be adsorbed on the sites of hydroxyls of the octahedron of $\mathrm{Al}$, exposed by fractures, Scrubs or crystalline lattice imperfections, or by interactions with the Fe oxides and hydroxides and $\mathrm{Al}$ amorphous. This occurs from adsorption of hydrogen bonds, which can also occur with water strongly adsorbed on the surface of the clay minerals (Fig. 12). 


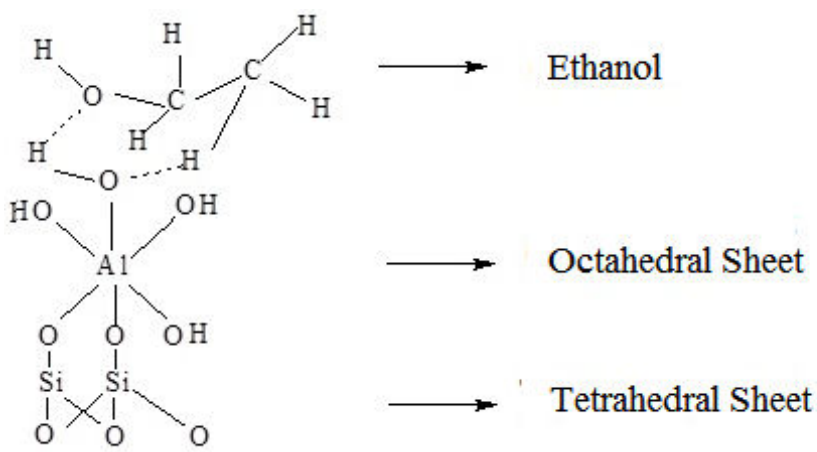

Figure 12. Coordination of interaction of hydrogen and hydroxyl ethanol exposed in the clay mineral (1:1).

\section{Discussion of the results}

The discussion of the results is focused on three main aspects. The first considers mineralogical, chemical and physical characteristics of the material with potential for liners. The second aspect is assessed the performance of Laterite soil on gasoline hydrocarbon flow subjected to high hydraulic gradients, causing an acceleration of the process of formation of flow channels for compressed soil in power of Proctor. The last aspect to be evaluated is the power of gasoline hydrocarbon adsorption by soil with OM and no OM.

\subsection{The delimiters criteria material with potential for liners}

Evaluating the criteria prescribed by Rowe et al., (1995) the soil presents considerable levels of Fe oxides and hydroxides and $\mathrm{Al}$ (hematite, goethite and gibbsite) and kaolinite with only $30.2 \%$ of quartz. As the mineral vermiculite is low soil activity levels was 0.18 , less than the 0.3 suggested by the literature. However this value of activity indicates that the material is not expandable, being a good quality for liners. The cationic exchange capacity (CEC) also presented low value $\left(6.4 \mathrm{mmol}_{\mathrm{c}} / \mathrm{dm}^{3}\right)$ comparing with value defined in literature. Tropical soils lateritic in general are highly weathered with low or no mineral content of 2:1, which are typical of temperate climate. Therefore, the activity and CEC are low. The granulometry performed $65 \%$ clay fraction indicated more than $20 \%$ of particles less than $2 \mathrm{~mm}$ confirming the material rich in clay fraction indicating low permeability material when compressed. Thus, the hydraulic conductivity parameter value introduced into water in the order $10^{-7} \mathrm{~cm} / \mathrm{sec}$ subjected to a pressure of $20 \mathrm{kPa}$ (Tab. 1). These results of the hydraulic conductivity characterize the material with great potential for liner according to predefined values in the literature.

\subsection{Lateritic soil performance as Liner}

The hydraulic conductivity of gasoline type $C$ brazilian obtained values between $10^{-8}$ to $10^{-7}$ $\mathrm{cm} / \mathrm{s}$ to a gradient of 75 with a pressure of $50 \mathrm{kPa}$, which corresponds to $5 \mathrm{~m}$ of the water 
column (Fig. 4). Such a result of hydraulic conductivity defines the material as great for barrier on gasoline hydrocarbon flow according to predefined values in literature (Rowe et al., 1995; Daniel and Koerner, 1995). With the increase of the hydraulic gradient there was an increase in hydraulic conductivity until it reaches a level of stabilization in gradient greater than 210 (Fig. 4). Although it does not occur to the destruction of the liner to the 210 to 450 gradients suggests avoid gradients greater than 100 in the projects of protection of underground fuel tanks, ensuring in this way a hydraulic conductivity around $10^{-7} \mathrm{~cm} / \mathrm{s}$ for liners according to the literature. The intrinsic permeability or specific considers simply the porous medium, not considering the characteristics of fluid. The values found for intrinsic permeability compacted laterite soil is similar to that found in the literature to clay (Freeze and Cherry, 1979).

The compacted soil voids indexes suffered increased 0.58 before tests to 0.77 with water flow and 0.90 with gasoline flow in hydraulic gradient of 75 . The empty volume also increased from 134.3 to 210.0 (Tab. 3). The soils studied presented a high degree of flocculation due to the aggregates of the oxyhydroxides of Fe and Al. Even when compacted, they contain microaggregates which are not destroyed. When a flow is established through the soil, the microaggregates may interconnect, forming flow channels. The physical behavior provoked by the flow may be visualized in the micromorphology of the samples in Fig. 8, 9 and 10. However even with these micros channels formed in the compacted soil hydraulic conductivity limit of $10^{-7} \mathrm{~cm} / \mathrm{s}$ (Daniel and Koerner, 1995) is not affected considering a gradient of 100.

\subsubsection{Adsorption performance for hydrocarbons of gasoline}

The performance of laterite soil to a gasoline hydrocarbon flow subjected to a pressure of 50 $\mathrm{kPa}$ with 75 gradient was evaluated for pore volume and the ratio $\mathrm{C} / \mathrm{Co}$ in the process of saturation of the compacted clay liner for gasoline, in other words, there was the expulsion of the water contained in the soil by the process of compression to achieve the optimum water content of compaction. The reason indicates that values above 1 there is an LNAPL phase concentration of groups of substances evaluated. The groups were evaluated for aromatic, olefins, saturated and ethanol.

In Fig. 7, the aromatic compounds appear as constants in the saturation process. Since they are hydrophobic, their polarity is low, and are more easily transported in the soil. The olefines and saturates have a greater C/Co ratio in the LNAPL due to their low solubility in water, being lower than the aromatic compounds, which are more affected by ethanol through co-solvency. In the 0.13 a 0.36 pore volume range, the ethanol is partitioned to the aqueous phase and, as the saturation of the pores with gasoline increases, the C/Co ratio for ethanol in the LNAPL also increases. The partitioning of the ethanol for the aqueous phase is natural and is due its polarity, which makes it mixable in water. Thus, the ethanol, along with the other hydrophobic compounds in the gasoline, favors the collapse of the double layer, as well as the increase in micropores (Rowe et al., 1995)

The results in Fig. 11 show that the soil organic matter, although in low quantities, has an influence of almost $0.41 \%$, in the sorption process. The soil studied was collected at a depth of 4 meters, thus contained evolved organic matter, possibly fulvic acid. The removal of the 
organic material with hydrogen peroxide showed low ethanol sorption. The aromatic compounds, which are hydrophobic, were not absorbed.

Evaluating the transportation of gasoline compounds by soil with application of $50 \mathrm{kPa}$ of pressure, indicates low retention and greater mobility, because mostly they are hydrophobic compounds that do not bind the soil particles. Another aspect of this experiment is that has not been evaluated by diffusion flux, which occurs at speeds equal to or less than $10^{-10} \mathrm{~cm} / \mathrm{s}$. The test of sorption to organic matter proved to be important in the retention process of ethanol. In view of the low adsorption of gasoline compounds by soil suggests considering projects of liners gradients below 75 and pressures less than $50 \mathrm{kPa}$ ensuring a hydraulic conductivity greater than $10^{-8} \mathrm{~cm} / \mathrm{s}$ and use clayey material rich in organic matter to promote greater retention of ethanol and avoid or reduce the effect of co-solvency.

\section{Conclusion}

Since the lateritic soil studied possesses a high aggregation capacity, even when compacted at normal Proctor energy, micropores remain which, in high hydraulic gradient situations, are interconnected, forming flow channels. However, even under higher hydraulic gradients in the gasoline percolation tests, this soil presents good material of liners. This is due to the stabilizing of the flow channels formed, favoring also the stabilizing hydraulic conductivity.

The measure that gasoline occupies the pores in the process of saturation the concentration of ethanol increases. This is due to the polarity of the ethanol. The aromatic compounds maintain a $\mathbf{C} / \mathbf{C}_{\mathbf{o}}$ ration close to 1 , as the volume of pores increases, indicating that these are tracers due to their low dielectric constant and polarity. Due to their low solubility in water, the olephines and saturates are more present in the LNAPL phase. These hydrocarbons may form emulsions, favoring transportation through the soil in the aqueous phase.

Regarding the retarding potential of the lateritic soil, evaluated by the sorption parameter, it is not directly correlated with the mineralogy, because the aromatic compounds are not absorbed when the organic material is extracted. Actually, this sorption may be correlated with a certain type of humic substance, which may be interacting with the poly-amorphs of the oxyhydroxides of $\mathrm{Fe}$ and $\mathrm{Al}$ in the soil, favoring interaction with the aromatic compounds.

Finally, a low hydraulic gradient context $(<75)$, hydraulic conductivity $<10^{-8}$ and organic matter, in lateritic soil can improve the performance of liner.

\section{Acknowledgements}

The authors are gratefully to the Conselho Nacional de Desenvolvimento Científico e Tecnológico - CNPq, CAPES and ANP for the fellowships and financial support granted to the accomplishment of this research. 


\section{Author details}

Wisley Moreira Farias ${ }^{1}$, Geraldo Resende Boaventura ${ }^{1}$, Éder de Souza Martins ${ }^{2}$, Fabrício Bueno da Fonseca Cardoso ${ }^{3}$, José Camapum de Carvalho ${ }^{1}$ and Edi Mendes Guimarães ${ }^{1}$

1 Universidade de Brasília, Brasília-DF, Brazil

2 Embrapa/ Cerrados, Planaltina -DF, Brazil

3 ANA-Agência Nacional de Águas -Brasília-DF, Brazil

\section{References}

[1] ABNT (1984) Solo - Determinação do limite de liquidez -NBR 6459/84.Associação Brasileira de Normas Técnicas, Rio de Janeiro, RJ, 6p.

[2] ABNT (1984) Solo - Determinação do limite de plasticidade - NBR7180/84. Associação Brasileira de Normas Técnicas, Rio de Janeiro, RJ, 3p.

[3] ABNT (1984) Solo - Grãos de solo que passam na peneira de 4,8 mm - Determinação da massa específica (método de ensaio) - NBR 6508/84. Associação Brasileira de Normas Técnicas, Rio de Janeiro, RJ, 8p.

[4] ABNT (1993) Rochas e solos - Terminologia - NBR 6502/93. Associação Brasileira de Normas Técnicas, Rio de Janeiro, RJ, 19p.

[5] Banerjee, S. and Yalkowsky, S.H. (1988). Cosolvent-Induced Solubilization of Hidrophobic Compounds into Water. Analytical Chemistry, v.60, p. 2153-2155.

[6] Barone, F.; Yanful, E.K.; Quigley, R.M. and Rowe, R.K. (1988). Effect of multiple contaminant migration of diffusion and adsorption of some domestic waste contaminants in a natural clayey soil. Geotechnical Research Report GEOT -5-88, Geotechnical Research Centre. The University of Westem Ontario, London, Ont.

[7] Cairney, S., Maruff, P., Burns C., Currie B (2002) The neurobehavioural consequences of petrol (gasoline) sniffing. Neuroscience and Biobehavioral Reviews, v.26:1, p. 81-89.

[8] Cardoso, F. B.F (1995) Análise Química, Mineralógica e Micromorfológica de Solos Tropicais Colapsíveis e o Estudo da Dinâmica do Colapso. Dissertação de Mestrado, Departamento de Engenharia Civil, Universidade de Brasília, Brasília, DF, 142p.

[9] Chiou, C.T., Porter, P.E. and Schmedding, D.W. (1983). Partition equilibrium of nonionic organic compounds between soil organic matter and water. Environmental Science and Technology, 17(4):227-231. 
[10] Cline, P.V., Delfino, J.J. and Rao, P.S.C. (1991). Partitioning of aromatic constituents into water from gasoline and other complex solvent mixtures. Environmental Science and Tecnology, 25(5):914-920.

[11] Corseuil, H. X. ; Fernandes, M.(1999). Efeito do Etanol no Aumento da Solubilização de Compostos Aromáticos Presentes na Gasolina Brasileira. Revista Engenharia Sanitária e Ambiental, v. 4, n. 1 e 2, p. 71-75.

[12] Daniel, D.E and Koerner, R.M. (1995) Waste containment facilities -Guidance for construction, Quality Assurance and Quality Control of Liner and Cover Systems, American Society of Civil Engineers, ASCE Press, New York, 354 pp.

[13] Donahue, R.B., Borbour, S.L. and Headley, J.V. (1999). Diffusion and adsorption of benzene in Regina clay. Canadian Geotechnical Journal, 36(3):430-442.

[14] FAO, IUSS Working Group WRB ( 2007). World Reference Base for Soil Resources 2006, first update 2007. World Soil Resources Reports No. 103, Rome.

[15] Farias, W.M. (2003). Condutividade Hidráulica de Solos Tropicais Compactados a Hidrocarbonetos da Gasolina. M.Sc. thesis, Department of Civil and Environmental Engineering, University of Brasilia, Brasilia DF, 152 pp.

[16] Fernandez, F. and Quigley, R.M. (1985). Hydraulic conductivity of natural clays permeated with simple liquid hydrocarbons. Canadian Geotechnical Journal, 22:205-214.

[17] Fernandez, F. and Quigley, R.M. (1988). Viscosity and dieletric constant controls on the hydraulic conductivity of clayey soils permeated with water - soluble organics. Canadian Geotechnical Journal, 25:582-589.

[18] Freeze, R. A. and Cherry, J. A (1979). Groundwater. Prentice-Hall, New Jersey, USA, $604 \mathrm{p}$.

[19] Karickhoff, S.W., Brown, D.S. and Scott, T.A. (1979). Sorption of hydrophobic pollutants on natural sediments. Water Research, 13:241-248.

[20] Martins, E.S., (2000). Petrografia, Mineralogia e Geomorfologia de Rególitos latériticos do Distrito Federal. Tese de Doutorado, Instituto de Geociências, Universidade deBrasília, Brasília, DF, 196 p.

[21] McDowell, C.J. and Powers, S.E. (2003). Mechanisms Affecting the infiltration and distribution of ethanol-blended gasoline in the vadose zone. Environmental Science and Technology, 37:1803-1810.

[22] Mesry, G. and Olson, R.E. (1971). Mechanisms controlling the permeability of clays. Clay and Clay Minerals, 19(3):151-158.

[23] Mussell Soil Color Company (1975) Mussell soil color charts. Baltimore, 1V, 117p. 
[24] Pastore, E.L. and Mioto, J.A. (2000). Impactos ambientais em mineração com ênfase à drenagem mineira ácida e transporte de contaminantes. Solos e Rochas. São Paulo, SP, 23(1):33-53.

[25] Rowe, R.K. (1988). Contaminant migration though groundwater: The role of modeling in the design of barriers. Canadian Geotechnical Journal, 25(4):778-798.

[26] Rowe, R.K., Quigley, R.M. and Booker, J.R. (1995). Clayey Barrier Systems for Waste Disposal Facilities. E and FN Spon, London, England, 390p.

[27] Scharzenbach, R.P., Gschwnd, P.M. and Imboden, D.M. (1993). Environmental Organic Chemistry. Wiley Interscience, New York, NY, 1313p.

[28] Shackelford, C.D. and Daniel, D.E. (1991). Diffusion in saturated soil. II: Results for compacted clay. Journal of Geotechnical Engineering, 117(3): 485-506.

[29] Ulrich, G. (1999). The Fate and Transport of Ethanol-Blended Gasoline in the Environment. Governors' Ethanol Coalition, Lincoln, Nebraska, 88p. 
